\title{
HASIL BELAJAR IPA BERDASARKAN GAYA BELAJAR SISWA
}

\author{
Tri Ambarwati Adawiyah ${ }^{1}$, Aloisius Harso ${ }^{2}$, Adrianus Nassar ${ }^{3}$ \\ Universitas Flores ${ }^{1,2,3}$ \\ triadawiyah98@gmail.com ${ }^{1}$
}

\begin{abstract}
This study aims to determine the differences in science learning outcomes of class VIII students of SMP Negeri 1 Larantuka who have visual, auditory and kinesthetic learning styles for the 2019/2020 academic year. The samples in this study were class VIII I and VIII J SMP Negeri 1 Larantuka. The research method used is quantitative with data analysis techniques using One Way Anova. Student learning styles are measured using a questionnaire that has been tested for validity and reliability first. Meanwhile, the learning outcome variable used the documentation method. The results of the F test showed that the value of Fcount <Ftable is $0.198<2.53$ with a significance value of $0.821>0.05$. In conclusion, there is no significant difference in science learning outcomes between students who have visual, auditory and kinesthetic learning styles.
\end{abstract}

Keywords: Learning Style; Science Learning Outcomes

Abstrak: Penelitian ini bertujuan untuk mengetahui perbedaan hasil belajar IPA siswa kelas VIII SMP Negeri 1 Larantuka yang memiliki gaya belajar visual, auditorial dan kinestetik tahun pelajaran 2019/2020. Sampel pada penelitian ini adalah kelas VIII I dan VIII J SMP Negeri 1 Larantuka. Metode penelitian yang digunakan adalah kuantitatif dengan teknik analisis data menggunakan One Way Anova. Gaya belajar siswa diukur menggunakan angket yang telah diujikan validitas dan reliabilitas terlebih dahulu. Sedangkan untuk variabel hasil belajar digunakan metode dokumentasi. Hasil pengujian uji $F$ menunjukkan bahwa nilai $F_{\text {hitung }}<F_{\text {tabel }}$ yaitu0,198 $<2,53$ dengan nilai signifikansi $0,821>0,05$. Simpulan, tidak terdapat perbedaan yang signifikan pada hasil belajar ipa antara siswa yang memiliki gaya belajar visual, auditorial dan kinestetik.

Kata Kunci: Gaya Belajar; Hasil Belajar IPA

\section{PENDAHULUAN}

Pendidikan merupakan suatu usaha atau kegiatan yang dijalankan dengan sengaja, teratur dan berencana dengan maksud untuk mengubah atau mengembangkan perilaku sesuai dengan yang diinginkan. Sekolah sebagai lembaga formal merupakan sarana dalam rangka pencapaian tujuan pendidikan tersebut. Melalui sekolah, siswa belajar berbagai macam hal, baik berupa intelegensi, kreativitas dan sosial. Upaya peningkatan mutu lulusan pendidikan, khususnya pendidikan di sekolah, tidak terlepas dari masalah hasil belajar yang dicapai oleh siswa.

Hasil belajar yang maksimal didapatkan atas usaha yang sungguhsungguh dari siswa maupun guru sebagai pendidik. Salah satu faktor yang mempengaruhi hasil belajar siswa adalah gaya belajar. Pendidik yang mengenal gaya belajar siswa akan lebih mudah memahami keragaman gaya belajar siswa dalam menerima dan memproses suatu informasi. Banyak siswa yang gagal dalam menerima informasi karena ketidaksesuaian gaya mengajar guru dengan gaya belajar siswa.

Gaya belajar merupakan sebuah metode yang dimiliki individu untuk mendapatkan informasi. Menurut Sugihartono (2007) gaya belajar merupakan kumpulan karakteristik pribadi yang membuat suatu pembelajaran menjadi lebih efektif untuk beberapa orang. Hal ini sejalan dengan Pujiarti (2013) yang menyatakan bahwa siswa mempunyai pencapaian akademik yang lebih cemerlang dan mempunyai sikap yang lebih positif terhadap pembelajaran apabila cara pengajaran 
disesuaikan dengan gaya belajar siswa. Pendidik yang mengenal gaya belajar siswa akan memahami keragaman gaya siswa dalam menerima dan memproses suatu informasi. Oleh sebab itu, para guru perlu merancang strategi dan teknik pengajaran dan pembelajaran yang bersesuaian dengan gaya pembelajaran yang berbeda-beda di kalangan siswa.

Banyak peneliti di Indonesia yang telah melakukan penelitian untuk mengetahui gaya belajar siswa. Penelitian tersebut lebih banyak memfokuskan pada tiga gaya belajar yakni visual, auditorial dan kinestetik. Seperti penelitian yang dilakukan oleh Depoter \& Hernacki (2016) yang menjelaskan bahwa secara umum gaya belajar manusia dibedakan dalam tiga kelompok besar yaitu gaya belajar visual, gaya belajar auditorial dan gaya belajar kinestetik. Gaya belajar visual adalah gaya belajar dengan cara melihat, mengamati, memandang dan sejenisnya. Kekuatan gaya belajar ini terletak pada indera penglihatan. Gaya belajar Auditorial adalah gaya belajar dengan cara mendengar. Individu dengan gaya belajar ini, lebih dominan dalam menggunakan indera pendengaran untuk melakukan aktivitas belajar. Sedangkan gaya belajar kinestetik adalah gaya belajar dengan cara bergerak, bekerja dan menyentuh. Gunawan (2006) mengemukakan bahwa hasil riset menunjukkan siswa yang belajar dengan menggunakan gaya belajar mereka yang dominan saat mengerjakan tes akan mencapai nilai yang jauh lebih tinggi dibandingkan bila mereka belajar dengan cara yang tidak sejalan dengan gaya belajar mereka.

Berdasarkan Hasil wawancara dengan guru mata pelajaran IPA di SMP Negeri 1 Larantuka peneliti dapat mencermati penyebab rendahnya hasil belajar IPA siswa di sekolah karena guru belum mampu menjembatani keragaman gaya belajar yang dimilki oleh siswa. Hasil belajar siswa dapat dilihat dari tingkat pencapaian standar kompetensi dan standar ketuntasan minimum yang ditentukan yaitu 75. Pada mata pelajaran IPA, terlihat masih banyak siswa yang belum mencapai kriteria ketuntasan minimal (KKM) yang ditetapkan yaitu 75. Hal ini dapat dilihat pada tabel 1.

Tabel 1. Nilai UTS Semester Genap Mata Pelajaran IPA Kelas VIII SMP Negeri 1 Larantuka

\begin{tabular}{cccc}
\hline Kelas & $\begin{array}{c}\text { Jumlah } \\
\text { Siswa }\end{array}$ & $\begin{array}{c}\text { Tuntas } \\
(>75)\end{array}$ & $\begin{array}{c}\text { Tidak Tuntas } \\
(<75)\end{array}$ \\
\hline VIII I & 30 & 8 & 22 \\
VIII J & 30 & 10 & 20 \\
\hline Jumlah & 60 & $30 \%$ & $70 \%$ \\
\hline
\end{tabular}

(Sumber: SMP Negeri 1 Larantuka)

Berdasarkan tabel 1dapat dilihat bahwa nilai IPA yang dicapai oleh kelas VIII dengan jumlah siswa sebanyak 60 orang terdapat 18 siswa (30\%) yang tuntas dan 42 siswa $(70 \%)$ yang belum tuntas.Tingkat keberhasilan yang dicapai oleh siswa setelah mengikuti suatu kegiatan pembelajaran dinyatakan dalam bentuk nilai atau simbol disebut hasil belajar.

Berdasarkan permasalahan di atas, peneliti tertarik untuk melakukan kajian mengenai pengaruh gaya belajar terhadap hasil belajar ipa siswa kelas VIII smp negeri 1 larantuka tahun pelajaran 2019/2020.

\section{LANDASAN TEORI \\ Gaya Belajar (Learning Style)}

Salah satu karakteristik belajar yang berkaitan dengan menyerap, mengolah dan menyampaikan informasi adalah gaya belajar. Penyerapan informasi tergantung pada cara seseorang dalam mengusahakannya. Menurut Nasution (2010) gaya belajar berkaitan erat dengan kepribadian seseorang.

Gaya belajar menggambarkan bagaimana orang-orang memahami dan mengingat informasi. James \& Gardner (1995) menyatakan bahwa gaya belajar adalah cara yang kompleks dimana siswa menganggap dan merasa paling efektif dan efisien dalam memproses, 
menyimpan, dan memanggil kembali apa yang telah mereka pelajari. Keefe (1979) mendefenisikan bahwa gaya belajar adalah faktor-faktor kognitif, afektif dan fisiologis yang menyajikan beberapa indikator yang relatif stabil mengenai bagaimana para siswa merasa, berhubungan dengan yang lain dan berinteraksi terhadap lingkungan belajar. Lincold \& Radhermocher (2006) mengatakan bahwa Gaya belajar dapat berubah dan berkembang sesuai dengan usia pembelajaran.

Berdasarkan uraian di atas dapat disimpulkan bahwa gaya belajar adalah suatu tindakan atau cara seseorang yang dianggap paling efisien dan efektif yang berkaitan dengan faktor-faktor kognitif, afektif dan fisiologis dalam menyerap informasi tentang apa yang mereka pelajari.

\section{Gaya Belajar Visual}

Gaya belajar visual adalah gaya belajar dengan cara melihat sehingga mata memegang peranan penting (Deporter \& Hernacki, 2016; Sudjana, 2010). Gaya belajar secara visual dilakukan seseorang untuk memperoleh informasi seperti melihat gambar, diagram, peta, poster, grafik dan sebagainya.

Ciri-ciri gaya belajar visual menurut Restianim et al., (2020) yakni; 1) senang kerapian dan ketrampilan; 2) jika berbicara cenderung lebih cepat; 3) ia suka membuat perencanaan yang matang untuk jangka panjang; 4) sangat teliti sampai ke hal-hal yang detail sifatnya; 5) mementingkan penampilan, baik dalam berpakaian maupun presentasi; 6) lebih mudah mengingat apa yang dilihat, dari pada yang didengar; 7) mengingat sesuatu melalui pengambaran (asosiasi) visual; 8) ia tidak mudah terganggu dengan keributan saat belajar (bisa membaca dalam keadaan ribut sekali pun); 9) ia adalah pembaca yang cepat dan tekun; 10) lebih suka membaca sendiri dari pada dibacakan orang lain;
11) tidak mudah yakin atau percaya terhadap setiap masalah atau proyek sebelum secara mental merasa pasti; 12) suka mencoret-coret tanpa arti selama berbicara di telepon atau dalam rapat; 13) lebih suka melakukan pertunjukan (demonstrasi) dari pada berpidato; 14) lebih menyukai seni dari pada musik; 15) sering kali mengetahui apa yang harus dikatakan, akan tetapi tidak pandai memilih kata- kata; 16) kadang-kadang suka kehilangan konsentrasi ketika mereka ingin memperhatikan. ciri-ciri bahasa tubuh yang menunjukkan seseorang gaya belajar visual yaitu biasanya duduk tegak dan mengikuti penyaji dengan matanya.

\section{Gaya Belajar Auditorial}

Gaya belajar auditorial adalah gaya belajar yang dilakukan seseorang untuk memperoleh informasi dengan memanfaatkan indra telinga. Oleh karena itu, orang tersebut sangat mengandalkan telinganya untuk mencapai kesuksesan belajar (Asriyanti \& Jannah, 2018). Mereka sangat menikmati saat-saat mendengarkan apa yang disampaikan oleh orang lain dengan kata lain, ia mudah belajar, mudah menangkap stimulus atau rangsangan apabila melalui alat indera pendengaran (telinga). Siswa yang memiliki gaaya belajar auditorial akan mudah mempelajari bahan-bahan yang disajikan dalam bentuk suara (ceramah), begitu dosen menerangkan ia cepat menangkap bahan pelajaran, disamping itu kata dari teman (diskusi) atau suara radio/video, ia mudah menangkapnya. Mahasiswa dengan gaya belajar auditorial akan mengalami kesulitan memahami konsep dalam bentuk tulisan, perabaan, gerakangerakan yang ia mengalami kesulitan.

Ciri-ciri gaya belajar auditorial menurut Wiyani (2013) dan Nurmayani (2016) yakni; (1) berbicara sendiri saat kerja; (2) mudah terganggu oleh keributan; (3) menggerakan bibir mereka dan mengucapakan tulisan dibuku ketika 
membaca; (4) senang membaca dan mendengarkan; (5) dapat mengulang kembali dan menirukan nada, birama dan warna suara; (6) merasa kesulitan dalam menulis tetapi hebat dalam bercerita; (7) biasanya lebih suka music daripada seni; (8) suka berbicara, berdisukusi dan menjelaskan sesuatu secara panjang lebar.

\section{Gaya Belajar Kinestetik}

Menurut Hasrul (2009) gaya belajar kinestetik adalah gaya belajar dimana siswa cenderung belajar melalui gerakan dan sentuhan. Kecenderungan gaya belajar kinestetik lebih melibatkan aktivias fisik. Mereka akan berhasil dalam pembelajaran apabila mereka mendapatkan sebuah kesempatan untuk memanipulasi media untuk mendapatkan informasi baru. Siswa yang memiliki gaya belajar kinestetik akan sulit duduk diam selama berjam-jam karena mereka lebih senang untuk beraktifitas.

Ciri-ciri gaya belajar Kinestetik menurut Wiyani (2013) dan Nurmayani (2016) yakni: (1) berbicara dengan perlahan; (2) menanggapi perhatian fisik; (3) menyentuh orang untuk mendapatkan perhatian mereka; (4) selalu berorientasi pada fisik dan banyak bergerak; (5) suka belajar melalui memanipulasi dan praktek; (6) suka menghafal dengan cara berjalan dan melihat; (7) banyak menggunakan bahasa tubuh; (8) tidak dapat duduk dalam waktu yang lama.

Ketiga gaya belajar yang telah dikemukakan sebelumnya merupakan gaya belajar yang sering dipakai oleh para peneliti untuk meneliti gaya belajar peserta didik.

\section{Hasil Belajar IPA}

Hasil belajar merupakan perubahan tingkah laku secara secara keseluruhan, bukan hanya dari satu aspek kemanusiaan saja. Hasil belajar ditandai dengan terjadinya hubungan subtantif antara aspek-aspek, konsep dan informasi baru dari komponen-komponen yang relavan dalam struktur kognitif peserta didik. Hasil belajar merupakan hasil dari suatu interaksi tindak belajar dan tindak mengajar (Slameto, 2013; Maisaroh \& Rostrieningsih, 2010). Hasil dari proses belajar diukur dalam bentuk tes. Tes tersebut disusun secara terencana baik tes lisan, tertulis, maupun tes perbuatan (Sudjana, 2014). Secara garis besar Benyamin Bloom membagi hasil belajar menjadi 3 ranah, yaitu ranah psikomotorik, kognitif dan ranah afektif. Secara eksplisit 3 ranah ini tidak dapat dipisahkan satu sama lain.

Berdasarkan uraian di atas dapat disimpulkan bahwa hasil belajar adalah perubahan tingkah laku yang diperoleh dari suatu interaksi tindak belajar dan tindak mengajar secara menyeluruh yang mencakup dalam 3 ranah yaitu, ranah psikomotorik, kognitif, dan afektif dan hasil pengukurannya dicapai dalam bentuk tes.

Dalam penelitian ini ranah belajar yang di gunakan untuk mengukur hasil belajar adalah ranah belajar kognitif. Ranah kognitif lebih dikenal dengan Taksonomi Bloom. Menurut Haryati (2013) kemampuan kognitif dibagi menjadi 6 tingkatan yaitu: 1) tingkat pengetahuan (knowledge), pada tahap ini menuntut siswa untuk mampu mengingat berbagai informasi yang diterima sebelumnya seperti fakta, rumus, terminologi strategi problem solving dan lain sebagainya; 2) tingkat pemahaman (compreshension), pada tahap ini kategori pemahaman dihubungkan dengan kemampuan untuk menjelaskan pengetahuan, informasi yang telah diketahui dengan kata-kata sendiri; 3) tingkat penerapan (application), pada tahap ini siswa di minta untuk menggunakan atau menerapkan informasi yang telah dipelajari ke dalam situasi baru, serta memecahkan berbagai masalah yang timbul dalam kehidupan sendiri.

Selanjutnya, 4) tingkat analisis (analysis), pada tahap ini siswa 
diharapkan dapat menunjukkan hubungan antara berbagai gagasan dengan cara membandingkan gagasan tersebeut dengan standar, prinsip, atau prosedur yang telah dipelajari; 5) tingkat sintesis (synthesis), merupakan kemampuan seseorang dalam mengaitkan dan menyatukan berbagai elemen dan unsur pengetahuan yang ada sehingga terbentuk pola baru yang lebih menyeluruh; 6) tingkat evaluasi (evaluation), merupakan level tertinggi yang mengharapkan peserta didik mampu membuat penilaian dan keputusan tentang nilai suatu gagasan, metode, produk atau benda dengan menggunakan kriteria tertentu.

Tabel 2. Taksonomi Ranah Kognitif

\begin{tabular}{ll}
\hline \multicolumn{2}{c}{ Taksonomi Ranah Kognitif } \\
\hline Mengingat & Mengurutkan, menjelaskan, \\
& mengidentifikasi, menamai, \\
& menempatkan, mengulangi \\
& dan menemukan kembali. \\
\hline Memahami & Menafsirkan, meringkas, \\
& mengklarifikasikan, \\
& membandingkan, \\
& menjelaskan dan \\
& memaparkan. \\
\hline Menerapkan & Melaksanakan, \\
& menggunakan, menjalankan, \\
& melakukan, mempraktikan, \\
& memilih, menyusun, \\
& memulai, menyelesaikan, \\
& dan mendeteksi. \\
\hline Menganalisis & Menguraikan, \\
& membandingkan, \\
& mengorganisasikan, \\
& menyusun ulang, mengubah \\
& struktur, mengerangkakan, \\
& menyusun outline, \\
& mengintegrasikan, \\
& membedakan, menyamakan \\
dan membandingkan.
\end{tabular}

(Sumber: Rusman, 2012)

\section{METODE PENELITIAN}

Jenis penelitian yang digunakan dalam penelitian ini adalah ex-post facto. Penelitian ex-post facto adalah penelitian tentang variabel yang kejadiannya sudah terjadi sebelum dilaksanakan penelitian. Variabel bebas dalam penelitian ini adalah gaya be;ajar dan variabel terikat adalah hasil belajar. Penelitian ini dilaksanakan pada semester genap kelas VIII SMP Negeri 1 Larantuka 2019/20120. Variabel dalam penelitian ini terdiri atas empat variabel yaitu tiga variabel bebas yakni visual, auditorial, dan kinestetik serta satu variabel terikat yakni hasil belajar IPA.

Adapun populasi dalam penelitian ini adalah seluruh siswa kelas VIII SMP Negeri 1 Larantuka tahun ajaran 2019/2020. Subjek dalam penelitian ini berjumlah 60 siswa yaitu pada kelas VIII I dan VIII J. Untuk memperoleh data yang diperlukan dari setiap variabel dalam penelitian ini, peneliti mengembangkan instrumen penelitian. Pada variabel bebas, Visual, auditorial dan kinestetik digunakan metode angket Sedangkan untuk variabel terikat yakni hasil belajar IPA digunakan metode dokumentasi berupa Hasil Penelian semester akhir (HPAS).

Suatu teknik analisis data menggunakan bantuan SPSS Versi 22 for Windows merupakan analisis deskriptif untuk mengetahui nilai rata-rata, nilai tertinggi dan terendah hasil belajar IPA sedangkan untuk mengetahui pengaruh gaya belajar terhadap hasil belajar IPA siswa digunakan analisis inferensial one way anova dengan ktiteria pengujian jika $\mathrm{F}_{\text {hitung }}<\mathrm{F}$ tabel maka tidak ada pengaruh gaya belajar terhadap hasil belajar IPA siswa dan sebaliknya apabila $\mathrm{F}$ hitung $<\mathrm{F}$ tabel maka ada pengaruh gaya belajar tethadap hasil belajar IPA siswa (Restianim et al., 2020). 


\section{HASIL PENELITIAN}

Gaya belajar bersifat individual bagi setiap orang dan untuk membedakan orang yang satu dengan orang yang lain. siswa yang mampu mengenali gaya belajarnya dengan baik akan menghasilkan suatu peningkatan hasil belajar. Gaya belajar merupakan salah satu faktor yang mempengaruhi hasil belajar.

Tabel 3. Hasil Analisis Uji F menggunakan One Way Anova.

\begin{tabular}{cccccc}
\hline \multicolumn{6}{c}{ ANOVA } \\
\hline \multicolumn{6}{c}{ Hasil Belajar } \\
\hline Types & $\begin{array}{c}\text { Sum of } \\
\text { Squares }\end{array}$ & Df & $\begin{array}{c}\text { Mean } \\
\text { Square }\end{array}$ & F & Sig. \\
\hline $\begin{array}{c}\text { Between } \\
\text { Groups }\end{array}$ & 6.663 & 2 & 3.331 & .198 & .821 \\
\hline $\begin{array}{c}\text { Within } \\
\text { Groups }\end{array}$ & 956.987 & 57 & 16.789 & & \\
\hline Total & 963.650 & 59 & & \\
\hline
\end{tabular}

Berdasarkan hasil pengujian hipotesis menggunakan one way anova dapat diketahui bahwa nilai $\mathrm{F}_{\text {hitung }}<\mathrm{F}_{\text {tabel }}$ yaitu $0,198<2,53$ dengan nilai signifikansi $0,821>0,05$. Dengan demikian dapat disimpulkan bahwa tidak terdapat perbedaan hasil belajar antara siswa yang memiliki gaya belajar visual, auditorial dan kinestetik.

\section{PEMBAHASAN}

Salah satu fakor penyebab tidak terdapatnya perbedaan hasil belajar antara siswa yang memiliki gaya belajar visual, auditorial dan kinestetik adalah penggunaan model atau metode pembelajaran yang bervariasi yang digunakan pada kurikulum 2013. Pada SMP Negeri 1 Larantuka sudah diterapkan kurikulum 2013 yang di dalamnya terdapat model atau metode pembelajaran yang bervariasi yang memungkinkan mampu mengakomodir semua jenis gaya belajar dalam proses belajar mengajar di kelas. Model dan metode pembelajaran yang digunakan tentunya mempunyai kelemahan dan kelebihan masing-masing sehingga dapat melengkapi satu sama lain.

Salah satu model pembelajaran yang biasa digunakan di sekolah adalah discovey learning dengan pendekatan saintifik. Pada pembelajaran IPA di kelas guru menggunakan metode pembelajaran yang menyentuh ketiga aspek sensori yaitu visual, auditorial dan kinestetik secara bersama-sama saat melaksanakan kegiatan belajar mengajar di kelas. Sebelum menjelaskan materi guru terlebih dahulu menyuruh siswa untuk membaca atau melihat ilustrasi yang ada pada buku siswa (visual), kemudian setelah membaca guru kemudian menyuruh siswa untuk berdiskusi (auditorial), setelah berdiskusi kemudian siswa melakukan percobaan (kinestetik). Dengan penggunaan metode ini tentunya dapat mencakup ketiga gaya belajar yang dimiliki oleh siswa sekaligus dalam kelas sehingga tidak terdapat perbedaan hasil belajar antara siswa yang memiliki gaya belajar visual, auditorial dan kinestetik.

Hal tersebut sejalan dengan penelitian yang dilakukan oleh Wijaya (2014) bahwa tidak terdapat perbedaan hasil belajar terhadap gaya belajar visual, auditorial dan kinestetik. Hal ini bisa saja terjadi karena nilai hasil belajar IPA yang diolah oleh peneliti diperoleh dari penilaian harian akhir semester (PHAS) yang sudah dikalkulasi dengan nilai-nilai tugas dan ulangan harian dan telah diperhitungkan melalui pertimbanganpertimbangan tertentu seperti nilai sikap siswa dikelas dan tuntutan bahwa siswa harus mencapai nilai KKM yang ditentukan di sekolah.

Hasil penelitian yang dilakukan oleh Wijaya (2014) sejalan dengan yang dilakukan oleh peneliti akan tetapi bertolak belakang dengan penelitian yang dilakukan oleh syofyan (2018) yang menunjukkan bahwa terdapat perbedaan hasil belajar antara siswa yang memiliki gaya belajar visual, auditorial dan kinestetik yang ditunjukkan pada hasil uji hipotesis yang menujukkan nilai $F_{\text {hitung }}>$ $F_{\text {tabel }}$ yaitu 3,662 > 3,204 dan nilai 
signifikan $0,029<0,05$, sehingga dapat disimpulkan bahwa terdapat perbedaan hasil belajar antara siswa yang memiliki gaya belajar visual, auditorial dan kinestetik. Oleh karena itu Seorang guru wajib mengetahui kecenderungan gaya belajar siswa-siswanya di dalam kelas agar tidak memberikan perlakuan yang sama antara individu satu dengan individu yang lainnya.

Seorang guru harus mampu untuk membedakan kebutuhan siswa masing-masing. Setelah mengetahui kecenderungan gaya belajar siswanya maka seorang guru akan mengetahui bagaimana metode yang tepat untuk menangani para siswa dengan kecenderungannya masing-masing agar penyerapan materi oleh siswa bisa maksimal. Siswa yang mempunyai kecenderungan gaya belajar visual, auditorial maupun kinestetik harus tetap belajar sesuai dengan kecenderungannya masing-masing.

Setiap siswa pada dasarnya mempunyai semua jenis gaya belajar namun hanya ada satu yang dominan. Setelah mengetahui jenis gaya belajar yang dominan pada dirinya, siswa harus menggali potensinya dengan gaya belajar yang dominan tersebut. Karena dalam penelitian ini, dijelaskan bahwa gaya belajar yang dominan pada seseorang entah gaya belajar visual, auditorial dan kinestetik adalahcara yang tepat digunakan untuk menyerap materi secara efektif dan efisien

\section{SIMPULAN}

Tidak terdapat perbedaan hasil belajar IPA antara siswa yang memiliki gaya belajar visual, auditorial maupun kinestetik.

\section{DAFTAR PUSTAKA}

Asriyanti, F. D., \& Jannah, L. A. (2018). Analisis Gaya Belajar Ditinjau dari Hasil Belajar Siswa. Jurnal Kajian Teori dan Praktik Kependidikan, 3(2), 183-187
Deporter, B., \& Hernacki, M. (2016). Quantum Learning: Membiasakan Belajar Nyaman dan Menyenangkan. Bandung: PT. Mizan Pustaka

Gunawan, A. W. (2006). Genius Learning Strategy Petunjuk Praktis untuk Menerapkan Accelarated Learning. Jakarta: Gramedia Pustaka Utama

Haryati, M. (2013). Model dan Teknik Penilaian pada Tingkat Satuan Pendidikan. Jakarta: Ciputat Mega Mall

Hasrul, H. (2009). Pemahaman tentang Gaya Belajar. Jurnal Medtek, 1(2), $1-9$

James, W. B., \& Gardner, D. L. (1995). Learning Style: Implications for Distance Learning. New Direction for Adult and Continuing Education, (67), 19-32

Keefe, J. W. (1979). An Overview In Nassp's Student Learning Style Diagnosis And Prescribing Program. JSTOR, 24(2), 138-144

Lincoln, F., \& Rademocher, B. (2006). Learning Style of ESL Student in Community Colleges. Community College Journal of Research and Practice, 30(5-6), 485-500

Maisaroh, M., \& Rostrieningsih, R. (2010). Peningkatan Hasil Belajar Siswa dengan Menggunakan Metode Pembelajaran Active Learning Tipe Quiz Team pada Mata Pelajaran Keterampilan Dasar Komunikasi di SMK Negeri 1 Bogor. Jurnal Ekonomi dan Pendidikan, 7(2), 157-172

Nasution, S. (2010). Berbagai Pendekatan dalam Proses Belajar dan Mengajar. Jakarta: Bumi Aksara

Nurmayani, M. Z. (2016). Pengaruh Gaya Belajar VAK pada Penerapan Model Pembelajaran Problem Based Learning terhadap Hasil Belajar IPA Fisika Siswa SMP Negeri 2 Narmada Tahun Ajaran 
2015/2016. Jurnal Pendidikan Fisika dan Teknologi, 2(1), 13-21

Pujiarti, A. (2013). Hubungan antara Gaya Belajar dengan Prestasi Belajar Siswa Kelas V SDN Percobaan 4 Wates Kulon Progo. Thesis. Universitas Negeri Yogyakarta

Restianim, V., Pendy, A., \& Merdja, J. (2020). Gaya Belajar Mahasiswa Pendidikan Matematika Universitas Flores Dalam Pemahaman Konsep Fungsi. Spej (Science and Phsics Education Journal), 3(2), 48-56

Rusman, R. (2012). Belajar dan Pembelajaran Berbasis Komputer. Bandung: Alfabeta

Slameto, S. (2013). Belajar dan FaktorFaktor yang Mempengaruhinya. Jakarta: Rineka Cipta

Sudjana, N. (2010). Dasar-Dasar Proses Belajar Mengajar. Bandung: Sinar Baru Algensindo
Sudjana, N. (2014). Penilaian Hasil Proses Belajar Mengajar. Bandung: Remaja Rosdakarya

Sugihartono, S. (2007). Psikologi Pendidikan. Yogyakarta: UNY Press

Syofyan, H. (2018). Analisis Gaya Belajar dan Motivasi Berprestasi terhadap Hasil Belajar IPA. Jurnal Eduscience, 3(2), 76-85

Wijaya, A. E. (2014). Pengaruh Kreativitas dan Gaya Belajar terhadap Hasil Tugas Akhir Siswa Mata Pelajaran Pengoperasian dan Perakitan Sistem Kendali di SMKN 2 Yogyakarta. Thesis. Universitas Negeri Yogyakarta

Wiyani, N. A. (2013). Manajemen Kelas Teori dan Aplikasi untuk Menciptakan Kelas yang Kondusif. Yogyakarta: Ar-Ruz Media 